\title{
Kekuatan Artificial Intelligence Tiongkok dan Kekhawatiran Masyarakat Global: Resensi Buku
}

\author{
Arief Bakhtiar Darmawan
}

Universitas Jenderal Soedirman

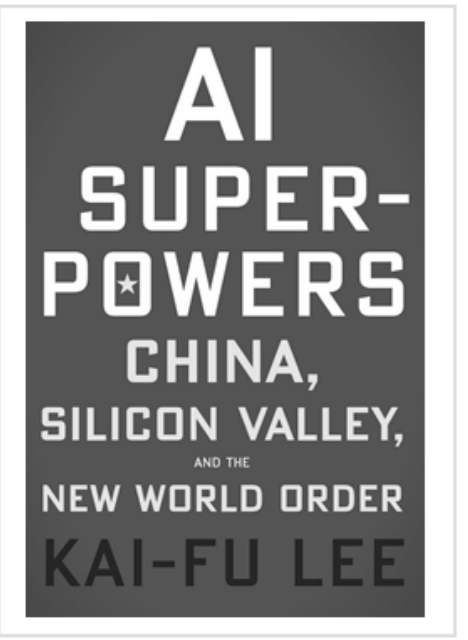

$\begin{array}{ll}\text { Judul } & \text { : AI Superpowers: China, Silicon } \\ & \text { Valley, and the New World } \\ & \text { Order } \\ \text { Penulis } & : \text { Kai-Fu Lee } \\ \text { Penerbit } & : \text { Houghton Mifflin Harcourt, } \\ & \text { Boston } \\ \text { Cetakan } & : 2018 \\ \text { Tebal } & : 253 \text { halaman }\end{array}$

Sejak awal sejarah manusia sampai sekitar satu abad yang lalu, manusia hanya mengenal dua wilayah yang secara fisik bisa dijelajahi, yaitu darat dan laut. Satu abad yang lalu, manusia menambah lagi wilayah fisik yang bisa dijangkau, yaitu udara, dimulai ketika Wright Bersaudara menemukan cara membuat pesawat terbang pada 1903. Pada pertengahan abad ke-20, manusia mulai mempelajari angkasa luar dan mengirim astronot untuk menjelajahi langit, dimulai dari Rusia yang meluncurkan Sputnik pada 1957. Memasuki era internet, manusia mulai menjelajahi wilayah kelima, yang kerap disebut cyberspace atau ruang siber. Dengan semakin pentingnya peran ruang siber, buku Kai-Fu Lee yang berjudul AI Superpowers: China, Silicon Valley, and the New World Order ini akan membawa kita berpikir kembali mengenai kemajuan umat manusia di bidang teknologi.

Ruang siber merupakan wilayah yang berkaitan erat dengan "penggunaan alat elektronik dan spektrum elektromagnetik untuk menyimpan, mengubah, atau bertukar informasi sampai lingkup global, melalui sistem informasi jaringan dan infrastruktur fisik yang mendukungnya" (Kuehl, 2009). Wilayah ini memiliki karakter yang unik karena meski tetap memerlukan teknologi, tetapi tidak lagi hanya mengandalkan ruang fisik sebagaimana darat dan laut. Di dalam ruang siber, manusia memiliki peluang untuk mengeksploitasi informasi, interaksi manusia, dan interkomunikasi. Dengan tiga unsur penting itu, ruang siber 
menyimpan potensi sebagai sumber kekuatan siber atau cyberpower bagi pihak pengguna, baik itu individu, perusahaan, maupun negara.

Memasuki abad ke-21, memanfaatkan ruang siber, manusia mengembangkan teknologi kecerdasan buatan yang diwakilkan oleh mesin. Dengan memasukkan data-data tertentu ke dalam ruang siber, mesin dibuat untuk memiliki pola pikir dan kemampuan kerja yang sama dengan manusia. Apakah manusia akan kalah oleh mesin itu? Pada 1997, juara dunia catur Garry Kasparov dikalahkan oleh mesin buatan IBM bernama Deep Blue. Selain membuktikan keunggulan atas manusia, kecerdasan buatan berpotensi membawa resiko tersendiri. Skandal pencurian data Cambridge Analityca dan Facebook untuk kampanye pemilu Donald Trump merupakan contoh penyalahgunaan eksploitasi ruang siber. Masyarakat Indonesia dan dunia juga sempat disibukkan dengan isu penyalahgunaan data pribadi oleh FaceApp. Isu itu dianggap penting karena melibatkan perusahaan asal Rusia, negara yang terkenal dengan teknologi peretasan. Di antara perusahaan besar, Huawei dan Samsung terlibat sengketa terkait dugaan pencurian teknologi. Di tengah rivalitas teknologi antara AS, Rusia, dan Tiongkok, apakah buku AI Superpowers: China, Silicon Valley, and the New World Order akan menjawab kekhawatiran yang ada?

Secara umum, Kai-Fu Lee berusaha menangkal tuduhan-tuduhan serius terhadap Tiongkok. Kai-Fu Lee membuka halaman-halaman awal dengan membahas keterkaitan antara Tiongkok dan Silicon Valley. Lee menyatakan kemenangan teknologi artificial intelligence (AI) perusahaan Barat atas dunia. Perusahaan seperti Google dan Facebook telah menjadi media pencari dan sosial terbesar di dunia. Raksasa teknologi internet tersebut dianggap melengkapi dominasi AS dalam dunia digital setelah dominasi kekuatan militer dan ekonomi pada tataran global (hal. 2). Di sisi lain, perusahaan teknologi Tiongkok punya cap sebagai peniru. Kasus tuduhan Donald Trump terhadap Huawei soal pelanggaran hak cipta teknologi merupakan salah satu kasus yang memperkuat cap tersebut. Untuk menjawab tuduhan itu, Kai-Fu Lee mengemukakan argumen bahwa dunia sedang mengalami transisi dari era penemuan ke era implementasi dan dari era keahlian ke era data (hal. 13-14).

Mengenai transisi yang pertama, persepsi bahwa AS dan Eropa merupakan penguasa AI muncul dari inovasi yang ditemukan oleh perusahaan teknologi AS dan Eropa. Namun, penemuan AI dianggap sebanding dengan penemuan listrik Thomas Alva Edison. Listrik merupakan penemuan revolusioner, tetapi terobosan itu bisa diaplikasi ke dalam banyak industri, sehingga manusia memakai listrik untuk memasak makanan, menerangi rumah, dan menjadi tenaga penggerak mesin industri. Demikian halnya dengan AI. AI merupakan terobosan teknologi, tetapi yang membuatnya berarti adalah aplikasi teknologi tersebut dalam kehidupan sehari-hari. Memahami perbedaan antara penemuan dan implementasi akan membantu kita melihat posisi Tiongkok dalam tatanan global dengan lebih positif. 
Dari sisi implementasi AI, perusahaan-perusahaan teknologi Tiongkok jelas tidak kalah dengan perusahaan AS dan Eropa. Kai-Fu Lee mengakui bahwa para teknisi Tiongkok mengamati teknologi Barat dan berusaha meniru sebaik mungkin, terutama hal mendasar seperti laman muka pengguna, arsitektur situs, dan pengembangan perangkat lunak di baliknya (hal. 34). Namun, begitu situs berjalan, maka para pebisnis Tiongkok dipaksa untuk memenuhi keinginan pasar. Mereka mempelajari apa yang sesuai dan tidak sesuai dengan pasar pengguna Tiongkok. Di situlah produk mengalami modifikasi dan lokalisasi. Sementara itu, produk-produk ternama dari Silicon Valley terus memaksakan modelnya untuk seluruh pengguna di dunia. Dengan demikian, perusahaan teknologi Tiongkok mengambil celah dari keengganan perusahaan AS untuk melakukan adaptasi lokal.

Kai-Fu Lee menangkis tuduhan yang kerap diarahkan kepada Tiongkok bahwa pemerintah komunis itu melakukan kebijakan proteksionisme untuk menangkal kompetitor dari AS. Menurut Lee, pendekatan Silicon Valley terhadap pasar merupakan penyebab terbesar kegagalan perusahaan teknologi Barat mengambil hati rakyat Tiongkok (hal. 39). Perusahaan AS menyamakan pasar Tiongkok dengan pasar negara lain di seluruh dunia, dan tidak memberikan fleksibilitas tim lokal untuk bersaing dengan para pebisnis kelas dunia di Tiongkok. Ketika Silicon Valley enggan mengevaluasi diri, Alibaba (meniru Amazon), Baidu (meniru Google), dan Tencent (meniru WhatsApp/LINE) sukses menyesuaikan diri dan mengambil pasar Tiongkok.

Mengenai transisi yang kedua, algoritma AI membutuhkan tiga hal untuk berjalan baik, yaitu data, kekuatan komputasi, dan kerja keras teknisi AI. Di sini, Tiongkok memiliki keunggulan karena kuantitas data bukan hal yang sulit bagi negara komunis dan terpusat seperti Tiongkok. Selain itu, menurut pengalaman Kai-Fu Lee, para teknisi AI Tiongkok memiliki mental kerja keras yang bahkan mungkin melebihi para teknisi di Silicon Valley. Di sebuah negara di mana budaya meniru merupakan hal yang dianggap biasa, inovatif dan kerja keras adalah sikap yang harus dimiliki untuk bertahan dalam ketatnya persaingan industri teknologi. Dengan modal tersebut, Kai-Fu Lee yakin bahwa Tiongkok akan segera mengungguli AS dalam mengembangkan AI.

Dari sisi data, banyaknya pengguna internet di Tiongkok memberikan keuntungan bagi kemajuan perusahaan AI. Namun, data tersebut bukan hanya soal kuantitas, tetapi juga kualitas. Perusahaan Silicon Valley mengumpulkan data dari aktivitas pengguna di ruang siber, seperti hal apa yang sering dicari, unggahan foto, video Youtube yang dilihat, dan semacamnya. Perusahaan Tiongkok berbeda. Mereka menggabungkan aktivitas di ruang siber dan di dunia nyata. Perusahaan Tiongkok mengumpulkan data mengenai makanan apa yang dibeli, seberapa besar cicilan yang diambil seseorang, kapan orang membeli produk, kapan menggunakan transportasi A, dan sebagainya. Seseorang bisa menggunakan 
WeChat untuk berkomunikasi, membayar produk di toko, memesan makanan, sampai memesan antrian ke dokter (hal. 54). Dengan data-data itu, AI memiliki banyak mata untuk menganalisis perilaku manusia secara detail.

Algoritma AI juga tidak memerlukan ahli untuk bisa berjalan dengan baik. Para teknisi Tiongkok telah cukup menguasai teknologi yang berkaitan dengan AI. Secara kultural, budaya kerja keras Tiongkok yang memiliki etos kerja tinggi membantu akselerasi perusahaan-perusahaan Tiongkok. Kai-Fu Lee menceritakan pengalaman Andrew $\mathrm{Ng}$, pendiri proyek Google Brain dan pemimpin proyek AI Baidu, mengenai etos kerja orang Tiongkok yang siap kapan pun untuk rapat, tanpa komplain sama sekali. Teknisi Tiongkok juga selalu merespon pesan Andrew dengan cepat. Jika teknisi Tiongkok membutuhkan satu jam untuk merespon, orang-orang Silicon Valley memerlukan satu hari untuk merespon masalah.

Dalam konteks tatanan dunia baru, sejak semula Kai-Fu Lee memperlihatkan bagaimana upaya keras Tiongkok menjadi "AI superpowers". Dengan menekankan pengembangan teknologi AI berbasis pasar (market-driven), Tiongkok memiliki target menjadi pusat inovasi global di bidang AI pada tahun 2030 (hal. 27). Pada saat ini, Tiongkok percaya diri bahwa perbedaan dengan Silicon Valley dalam penelitian AI hanya terpaut enam belas jam-setara perbedaan waktu Beijing dan California (hal. 87). Dalam beberapa tahun ke depan, Lee percaya bahwa AS dan Tiongkok akan memimpin implementasi teknologi AI dalam bidang-bidang produktif. Meski demikian, Lee turut mengakui, dalam skala global, negara yang memiliki teknologi AI mungkin saja melakukan monopoli industri dan meninggalkan negara yang lemah. Slogan Silicon Valley yang mendeskripsikan teknologi mereka sebagai "penghubung umat manusia" dan "pendorong untuk dunia yang lebih baik" bisa jadi tidak relevan. Pandangan itu saya anggap sebagai kelebihan buku ini. KaiFu Lee, yang memiliki pengalaman kerja di dua negara kuat seperti AS dan Tiongkok, berani berbagi kekhawatiran kemajuan teknologi.

Namun, pandangan-pandangan dalam buku ini memiliki kelemahan karena tidak secara jelas menjawab beberapa kekhawatiran masyarakat global, seperti pencurian data pribadi untuk urusan kriminal, perang siber antarnegara, atau pemanfaatan AI oleh negara untuk menindas rakyat yang berseberangan dengan rezim berkuasa. Pada halaman-halaman akhir, KaiFu Lee mengaku bahwa dirinya tidak terlalu tertarik pada perspektif politik. Ia menolak menyamakan perlombaan teknologi AI dengan perlombaan senjata saat Perang Dingin. Lee memilih bersikap optimis dengan melihat prospek AI untuk meningkatkan kemakmuran dan nilai ekonomi demi kesejahteran umat manusia dalam skala besar. Menurut saya, Lee terlalu utopis jika meniadakan perspektif persaingan politik atau keamanan militer. Sejarah telah membuktikan bahwa implementasi kemajuan teknologi di bidang sipil berasal dari pengembangan-pengembangan di bidang militer. Akibatnya, agresivitas Tiongkok dalam pengembangan teknologi AI bisa jadi membenarkan pandangan beberapa akademisi Barat yang melihat kebangkitan Tiongkok sebagai kemunculan villain (Zhao, 2013: 102). 
Meski demikian, dengan bahasa yang tidak terlalu rumit dalam menjelaskan teknologi, buku ini relevan untuk dipelajari, baik bagi pemerhati cyberpower di Indonesia secara khusus, maupun masyarakat secara umum. Selama ini, masyarakat Indonesia cenderung menjadi konsumen teknologi AI. Indonesia masih belum memiliki strategi nasional mengenai AI. Pada awal tahun 2020, Menteri Riset dan Teknologi Bambang Brodjonegoro telah menugaskan Badan Pengkajian dan Penerapan Teknologi (BPPT) untuk menyusun strategi nasional AI tersebut (Badan Pengkajian dan Penerapan Teknologi, 2020). Ketika dokumen tersebut rilis, kita pun masih akan menunggu cukup lama mengenai implementasi, operasionalisasi, serta institusionalisasi AI dalam pemerintahan. Yang lebih penting lagi, pemerintah Indonesia dan perusahaan dalam negeri harus segera bekerja sama mengambil peluang sebagai inisiator untuk mengembangkan teknologi AI demi meningkatkan kesejahteraan ekonomi masyarakat, alihalih terus menjadi konsumen teknologi AI yang dikembangkan perusahaan luar negeri.

\section{Daftar Pustaka}

Badan Pengkajian dan Penerapan Teknologi. 2020. Pemerintah Siapkan Strategi Nasional Kecerdasan Buatan (AI) [Online]. BPPT, 7 Mei. Tersedia di: <https://www.bppt.go.id/layanan-informasi-publik/3919pemerintah-siapkan-strategi-nasional-kecerdasan-buatan-ai> [Diakses 23 Juli 2020].

Kuehl, D.T. (2009). From Cyberspace to Cyberpower: Defining the Problem. Dalam Franklin D. Kramer, Stuart H. Starr, \& Larry K. Wentz, Cyberpower and National Security. Washington, DC: National Defense University Press.

Zhao, S. (2013). Chinese Foreign Policy as a Rising Power to find its Rightful Place. Perceptions 18(1), pp. 101-128. 